\title{
Rевевсн автіск: An effective transfer of agricultural mechanization technologies for farmers through multi-media tool
}

\author{
M. Chowda Reddy, C.K. Sudha, Murahari D. Naik and R. Chithiraicheluvan
}

Article Chronicle:

\section{Received :}

23.10.2017;

Revised :

15.12.2017;

Accepted :

01.01 .2018

KEY WoRdS:

Multi-media tool,

Mechanization,

Transfer of

technology,

WhatsApp

Author for correspondence :

\section{Chowda Reddy}

Department of

Agricultural Engineering,

Rai Technology

University,

Doddaballapura,

Bengaluru (Karnataka)

India

Email : chowdas705@

gmail.com

See end of the article for

authors' affiliations
SUMMARY : Social Media has been impacting on various sectors including the agriculture sector. Platform like WhatsApp tool is majorly encouraging interaction among users like lead farmers and educated farmers and in sharing of information among the farming community based on all size group of agrarians. Earlier days, farmers used to exchange agricultural information and tips on farming when they got together at a meeting place in the villages or depended on newspapers, farm related magazines, television and radio for news. Average number of messages seen by WhatsApp group members at "Krushi Mitra" group within one week, the messages related to general agriculture-85 (89.47\%), farm mechanization-86 (90.52\%), social-84 (88.42\%), personal -74 (77.89\%), humanity concern-85 (89.47\%), general awareness $-74(77.89 \%)$ and general discussion messages has been depends based on topic raised and intensity of topic. In the group total 81 questions has been asked by farmers at one season at various vegetable crops related farm equipments at various unit operations and all questions has been answered by experts through WhatsApp tool. Number of farmers doesn't know the equipments before posting equipments in WhatsApp group is (Land preparation-60\%, sowing and planting-55.55 $\%$, irrigation and fertigation-50\%, weeding-64.44\%, sparaying-61.11\%, harvesting-52.22\%, threshing$62.22 \%$ and cleaning and grading- $47.77 \%$ ). This study is conducted with a specific objective to suggest farmers to improve farm productivity and popularize the farm mechanization technologies among the various sizes of farmers at different crops at Chickaballapura, Kolar and Bengaluru Rural district through multi-media tool WhatsApp.

How to cite this article : Reddy, M. Chowda, Sudha, C.K., Naik, Murahari D. and Chithiraicheluvan, R. (2018). An effective transfer of agricultural mechanization technologies for farmers through multi-media tool. Agric. Update, 13(1): 43-47; DOI : 10.15740/HAS/AU/13.1/43-47. 